\title{
Z Miodogórza. Po męsku z kobiecej perspektywy (listy Żmichowskiej do „siostrzeńców z wyboru”)
}

DOI: http://dx.doi.org/10.12775/LC.2017.035

\begin{abstract}
Streszczenie: List dla Narcyzy Żmichowskiej (Gabrielli) to płaszczyzna intelektualnej aktywności, do której bywa skłaniany również odbiorca. W artykule analizie podlega wybrany fragment rozległej twórczości epistolograficznej pisarki. Listy, kierowane przez nią po powstaniu styczniowym do trzech młodych mężczyzn, są omawiane jako rodzaj cyklu, którego spójność kształtuje się za sprawą miejsca (Miodogórze, gdzie rodziła się wspólność ideowa), ukrytego bohatera (zmarly w cytadeli Edward Jurgens) oraz nadawcy maskującego swój prawdziwy status (kobieta-nauczycielka-przewodnik). W artykule przeanalizowano strategie i cele tak ukształtowanego podmiotu wypowiedzi epistolograficznej.
\end{abstract}

Słowa kluczowe: powstanie styczniowe, wspólnota ideowa, inicjacja, list, Narcyza Żmichowska

\section{From Miodogórze. Masculine from feminine perspective (the letters of Żmichowska to "chosen nephews")}

\begin{abstract}
The letter for Narcyza Żmichowska (Gabriella) is a sphere of an intellectual activity to which the reader is also at times encouraged. In the article the large piece of an epistolography, a significant part of Żmichowska literary work, is being analysed. The letters which She addressed, after the January Uprisal, to the three young men, are perceived as a cycle the integrity of which is being obtained through the place (Miodogórze where the common ideas were born), the concealed hero (Edward Jurgens who died in citadel) as well as through the person of the sender who tries to hide her real status (woman-teacher-guide). The article analyses the strategies and aims of a specific entity the voice of whom can be heard in the letters.
\end{abstract}

Key words: January Uprisal, the community of ideas, initiation, the letter, Narcyza Żmichowska

* Profesor w Zakładzie Literatury Polskiej Romantyzmu i Pozytywizmu Uniwersytetu Mikołaja Kopernika. Zajmuje się powieścią polską XIX wieku. E-mail: eowczarz@umk.pl. 


\section{Chronologia nadziei i wspomnień}

isty Narcyzy Żmichowskiej (Gabrielli), obejmujące swym chronologicznym zasięgiem ważną część polskiego XIX wieku, warto badać z tych samych powodów, dla których opracowuje się oraz tak pieczołowicie, wciąż od nowa, czyta korespondencje Słowackiego, Mickiewicza i Krasińskiego. Ale wskazać by można kilka innych przyczyn, niby też oczywistych, choć nie zawsze w pełni uświadamianych. Epistolografia Gabrielli, obszerna, licząca kilka tomów, starannie sukcesywnie wydawana ${ }^{2}$, jest ocaloną z zawieruchy dziejów rozmową (tak! rozmową, choć poznać możemy tylko listy Żmichowskiej, „słyszymy” zwykle obie strony komunikacji) tych, którzy tu, w kraju, pod okiem zaborcy, wiedli egzystencję cichą acz niepokorną; niepokorną nawet wtedy, gdy nie spiskowali. Zestawiona z listami wielkich naszych poetów emigrantów daje więc ogląd rzeczywistości polskiej z innej zgoła perspektywy. To inność wzmocniona faktem, iż na wielką historię (polską i europejską) patrzy (nie) ważna kobieta (guwernantka - dziewiętnastowieczny symbol kobiecej niezauważalności w świecie, ale też poetka, pisarka Gabriella - czasem wielbiona, czasem przeklinana jedna z najciekawszych, ważnych kobiet epoki) osadzona na prowincji w szerokim (Królestwo Polskie, Warszawa) i węższym (Rzeczyca, Olszowa, Dębowa Góra) tego słowa znaczeniu, która swoje zamierzenia w stosunku do słanych w różne strony świata listów elaboratów, zapisywanych gęsto na każdym skrawku papieru, tak określa (niech nie umknie nam ów kobiecy maksymalizm): „,... ten maczek, w którym ja bym cały świat nasz tutejszy jak w mikroskop ująć chciała”3. Warto sprawdzić, czy potwierdza to tezę Stefanii Skwarczyńskiej o skłonnościach piszących kobiet do ujęć szerokich, ale niegrzeszących głębią ${ }^{4}$.

Podobnie jak z epistolografii wymienionych romantyków (Słowackiego i Krasińskiego przede wszystkim) wydobyć z niej można rodzaj „powieści utajonej”s $\mathrm{w}$ listach, dotyczącej

\footnotetext{
1 Tak Ignacy Baranowski (Pamiętniki, Poznań 1923) podsumowuje opis sytuacji dotyczący wydarzeń w przedpowstaniowej Warszawie. Po wyczerpaniu argumentów i wyjściu dyskutantów Żmichowska rozpłakała się z bezsilności. Była więc kobietą, bo jej męska inteligencja nie wykluczała klasycznej demonstracji kobiecej bezradności. Zob. M. Stępień, Narcyza Żmichowska, Warszawa 1968, s. 367.

2 Już w 1885 roku ukazał się pierwszy zbiór listów (Listy do rodziny i przyjaciót), zniekształcony, podobnie jak drugie krakowskie wydanie z roku 1906, na skutek „cenzorskich” działań wydawczyń bezkrytycznie kultywujących pamięć pisarki. W latach 60. ubiegłego wieku ukazały się trzy obszerne tomy w opracowaniu Mieczysławy Romankówny: N. Żmichowska, Listy, t. I: W kręgu najbliższych, Wrocław 1957; t. II: Rozdroża, Wrocław 1960; t. III: Miodogórze, Wrocław 1967. Dwa następne, również obszerne tomy wyszły dopiero na początku XXI wieku: t. IV: Rozmowy z Julią, z rękopisu wydała B. Winklowa, Warszawa 2009; t. V: Narcyssa i Wanda, wydały B. Winklowa i H. Żytkowicz, Warszawa 2007.

3 N. Żmichowska do Erazma Żmichowskiego, Listy, t. I, s. 132

4 S. Skwarczyńska, Teoria listu, Lwów 1937, s. 71. Zob. również A. Pekaniec, Czy w tej autobiografii jest kobieta? Kobieca literatura dokumentu osobistego od początku XIX wieku do wybuchu II wojny światowej, Kraków 2013, s. $186-187$.

5 To trafne określenie Ewy Nawrockiej, które zaczerpnęłam z jej rozważań „[... ] list to nie stowo”. O listach Stowackiego do matki, [w:] Sztuka pisania. O liście polskim w wieku XIX, red. J. Sztachelska i E. Dąbrowicz, Białystok 2000, s. 113 (nlb.).
} 
epoki (dokument egzystencji) oraz samej autorki (dokument osobisty). Przy czym ten swoisty Entwicklungsroman ${ }^{6}$ odnosi się tyleż do niej samej, co niektórych spośród szczególnie przez nią ukochanych korespondentów. To skutek specyficznej, wspomnianej już „dialogowości” jej listów, ich czułego (ale nie czułostkowego) zainteresowania odbiorcą; przywoływania go po to, aby rozmowa, autentyczna, nie deklaratywna, odbywała się we wspólnej myślowej przestrzeni, a „litera martwa”, że przypomnimy ubolewania Słowackiego, stwarzała nie dystans, lecz szansę wyjątkowej szczerości. Pisała przecież do Henryka Wohla: „nie wiem, czy na żywe słowa mogę z kim prawdziwiej niż na pismo rozmawiać: [... ] łatwiej by mi było skłamać słowem jak literą” . Listy Gabrielli są więc zwykle „podarunkami szczerości” (M, III, 328) $)^{8}$.

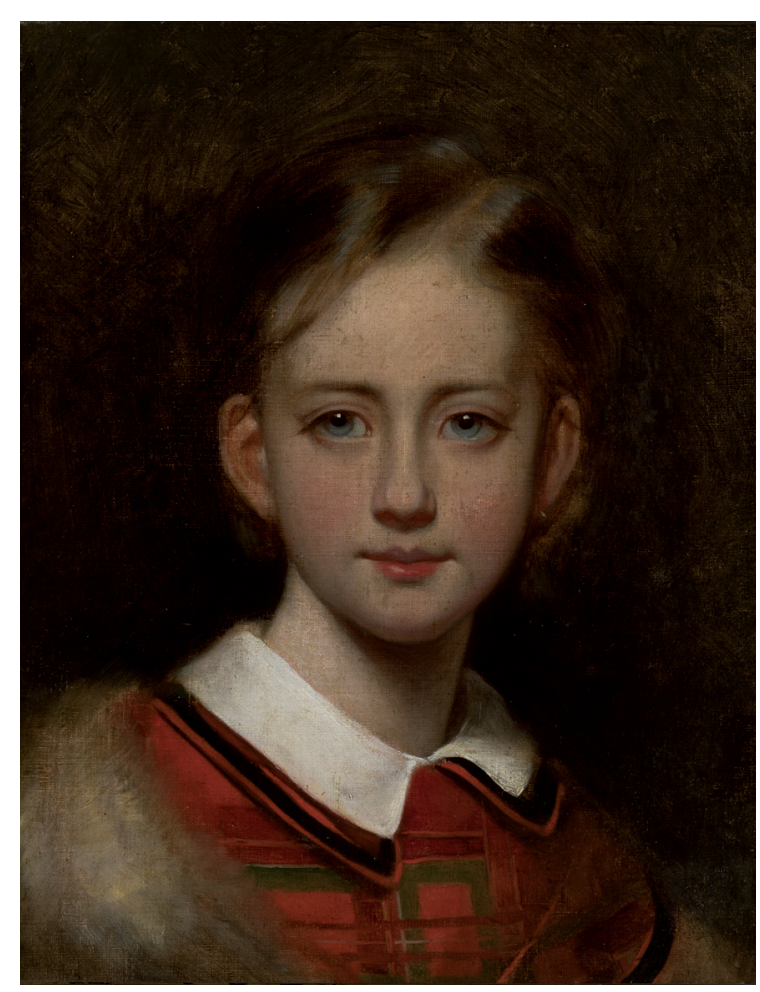

Artur Grottger, Portret dziewczynki

Fot. Krzysztof Wilczyński. Ze zbiorów Muzeum Narodowego w Warszawie

\footnotetext{
${ }^{6}$ Byłaby to sytuacja podobna do tej, jaką opisuje w odniesieniu do Słowackiego Michał Kuziak; zob. w cytowanym wyżej tomie artykuł Kreacje epistolograficzne Juliusza Stowackiego (zarys problematyki), s. 94.

7 N. Żmichowska, Listy, t. III: Miodogórze, do druku podała i komentarzem opatrzyła M. Romankówna, Wrocław 1967, s. 241. W dalszej części artykułu cytaty będę lokalizować bezpośrednio w tekście w następujący sposób: cyfra rzymska oznacza tom, arabska - stronę, litera W - listy do Henryka Wohla, M - do Seweryna Markiewicza, K - do Edwarda Kaplińskiego.

8 Wcześniej jej szczerość była trochę bardziej egzaltowana. W liście do brata Erazma pisała, że chce i może (list wysłany przez okazję) mówić „otwarcie i szczerze - duchem do ducha” (I, 152). To niemal kalka ze Słowackiego, który pisał do autora Irydiona: „... litera martwa i papier martwy pomiędzy duchem a duchem” (cyt. za: M. Kuziak, op. cit., s. 95). Listy Słowackiego znała: „a cudne on listy pisał ten Słowacki” (W, III, 252). Tak naprawdę to topos jeszcze sentymentalny. W Clarissie Richardsona bohater wyznaje, że „pisanie listów prywatnych” to „pisanie prosto z serca [...] mało z serca, prawdę rzekłszy z samej d u s z y” (zob. I. Watt, Narodziny powieści. Studia o Deffoe'em, Richardsonie i Fieldingu, thum. A. Kreczmar, Warszawa 1973, s. 226).
} 
Wydobycie powieści rozwojowej z wieloletniej korespondencji, ukazującej najpierw egzaltowaną panienkę, potem świadomą swych celów nauczycielkę, aż wreszcie „starą ciotkę”, nie jest szczególnie trudne. Żmichowska „znaczy” drogę, wskazuje miejsca węzłowe egzystencji (np. „radykalny przewrót moich usposobień” - W, III, 268). To wysiłek z pewnością opłacalny. Jako powieść rozwojowa listy mówią bowiem o tym, co mało znane (i etnologom, i badaczom literatury): o kobiecych, udanych i nieudanych inicjacjach w życie oraz świadomych i mniej świadomych w Historię. Czy więc - pisane z kobiecej perspektywy - prezentują Herstorię? Są jej zapowiedzią?

W całokształcie twórczości Gabrielli epistolografia ważna jest z jeszcze jednego powodu. Otóż list pełni ważką rolę w konstrukcji jej hybrydycznych utworów prozatorskich, co samo w sobie - jeśli pamiętać o początkach powieści europejskiej - wydaje się interesujące, ponieważ następuje $w$ nich przeformułowanie funkcji listów, przeniesienie jej z płaszczyzny uczuciowej na intelektualną9. Takie są znamiona nie tylko pisarstwa Żmichowskiej, ale jak sądzę - również jej korespondencji. Dodatkowo skłania do refleksji fakt znany z życia Krasińskiego: nasilenie korespondencji oznacza wyciszenie twórczości artystycznej aż do zamilknięcia. Żmichowska listy pisze do samej śmierci, natomiast do twórczości literackiej $\mathrm{z}$ wiekiem coraz trudniej daje się namówić. A jednak stopniowe wycofywanie się autorki z życia literackiego zdaje się mieć inne powody niż w przypadku Krasińskiego, bo na jej twórczość prozatorską list prywatny mógł działać raczej stymulująco ${ }^{10}$. Wszak rozpatrzenie problemu („kwestii”) z „najukochańszymi” inspirowało czasem do podobnych ujęć beletrystycznych, co nie oznacza wcale bezpośredniego transferu z życia do literatury. Tak pisze np. o utworze Kasia i Marynka, w którym wymiana listów staje się zaczynem powieściowym:

[... ] kiedy nagle wielkiego zażądano pospiechu, ze starych rzeczy wyciągnęlam jakiś ustęp i dopełniłam go, zgadnijcie, czym? ... listem Waszym i rozmową. No, nie lękajcie się znowu, bym Was podkradła jak francuski dziennikarz. Nie mam sobie do wyrzucenia nawet ani pół okresu zupełnie Waszego co do słów, tylko jest to trochę Wasze co do myśli, które po liście Waszym, po rozmowach przemyślałam (M, III, 336).

Widzimy, iż czerpanie z dokumentu osobistego jest tu zupełnie inne niż u młodej Nałkowskiej ${ }^{11}$, choć - należałoby to poddać głębszej refleksji naukowej - jak autorka Narcyzy myślała dziennikiem, tak autorka Poganki - listem. Kiedy jeden z jej tekstów List nie wiem czyj i nie wiem do kogo „Biblioteka Warszawska” wydrukowała pod zmienionym, zacierającym ślady listowości tytułem, Żmichowska zaprotestowała, argumentując, że forma utworu była świadomą w pełni przemyślaną decyzją.

Nie chodzi jednak o program badań nad epistolografią Gabrielli, ale o wytłumaczenie, iż każdy najmniejszy przyczynek dotyczący jej korespondencji ${ }^{12}$ poszerza wiedzę na temat

\footnotetext{
9 Na temat sentymentalnej tradycji powieści w listach zob. np. I. Watt, rozdz. Powieść a doświadczenie osobiste, [w:] idem, op. cit., s. 205-288. Tę tradycję w odniesieniu do Żmichowskiej warto byłoby prześledzić, ponieważ już u Richardsona obserwować można zwielokrotnienie punktów widzenia, przeplatanie męskiej i żeńskiej perspektywy oglądu itp.

10 W liście do Kaplińskiego pisała: „jeśli zamilkłam, to pewnie dlatego, iż nic nie mam do powiedzenia”. Ale zaraz uzupełniała: „bo mam właśnie pełną duszę tego, czego się mówić nie godzi, czego mówić nie chcę” (K, III, 299).

11 H. Kirchner, Natkowska albo życie pisane, Warszawa 2011.

12 Badań nad korespondencją Żmichowskiej jest niewiele w stosunku do ich znaczenia nie tylko w porządku jej twórczości. Oto ważniejsze z lat ostatnich: M. Woźniakiewicz-Dziadosz, Dzieje przyjaźni entuzjastek w świetle listów Narcyzy Żmichowskiej do Bibianny Moraczewskiej, Lublin 2002; eadem, List pisarza w przestrzeni autobiograficznej (Przypadek epistolo-
} 
całokształtu tej osobliwej twórczości ${ }^{13}$, na temat małych i wielkich problemów epoki oraz udziału w niej ludzi dziś już zapomnianych, a kiedyś całą swą egzystencję podporządkowujących sprawom ojczyzny.

W prezentowanych rozważaniach uwaga skupiona zostanie na bloku listów niewyodrębnionych specjalnie ani przez autorkę, ani też wydawców, zawartych w cytowanym już wyżej tomie III zatytułowanym Miodogórze. Są to listy z popowstaniowych lat 60 . i z początków lat 70. do Seweryna Markiewicza, Henryka Wohla i Edwarda Kaplińskiego. Ich spójność zasadza się nie tylko na czasie powstania, który oczywiście jest ważny, ponieważ określa w znacznej mierze tematykę listów oraz stopień ich „jawności” (instytucjonalne lub częściej pozainstytucjonalne, osłabiające pamięć o cenzurze, sposoby ich dostarczania), tak jak ważny jest fakt, iż są to listy kobiety do mężczyzn, bo może - jak Norwida listy do kobiet - są one najcenniejszą częścią jej spuścizny epistolograficznej ${ }^{14}$. Równie istotny pozostaje rodzaj więzów łączących korespondentów, ponieważ za ich sprawą epistolograficzna opowieść nabiera znamion uniwersalności i głębi, staje się relacją o czasach i ludziach, a nie pojedynczych losach. Więzy owe przez samą Żmichowską określane są jako „powinowactwa z wyboru”. Goetheańskie określenie najpełniej definiuje rodzaj stosunków łączących pisarkę z trójką mężczyzn o pokolenie od niej młodszych. I relacje te co pewien czas z ważnych powodów sobie, ale im przede wszystkim, uświadamia: „Raz już pisałam do Was przybrany i kochany mój siostrzeńcze" (W, III, 205) - zaczyna np. list do Wohla, gdy próbuje zadzierzgnąć stosunki przerwane na skutek zesłania młodego prawnika na Syberię. Do Kaplińskiego zwraca się w nagłówku listu: „najserdeczniejszy, najcenniejszy z adoptowanych siostrzeńców moich” (K, III, 291). Wcześniej „rodzeństwem wedle myśli”15 określała grono przyjaciół skupionych wokół „Przeglądu Naukowego”. W liście do Erazma z 1862 roku właśnie w kontekście pomiodogórskiej samotności, ale też w odniesieniu do całokształtu swych życiowych wyborów wyznawała: „garnęłam się ku najlepszym [...] co najpoczciwszych ogromadzałam, kochałam, łączyłam w jedno braterstwo rodzinne"16.

Miodogórze - wspólnota ideałów (,jednogatunkowa natura pragnień naszych i dążności” - M, III, 343) oraz Edward Jurgens - przyjaciel najserdeczniejszy, mentor całej czwórki, darzony przez Gabriellę, jak sądzą niektórzy badacze, nieodwzajemnionym uczuciem; przestrzeń i człowiek, oto co zespoliło więzami szczególnego rodzaju autorów omawianego bloku listów. Jurgens znajduje się zawsze w tle tej korespondencji; nawet jeśli w listach nie jest wprost wzmiankowany, perseweracyjne przewijanie się pewnych faktów i zdarzeń stawia go przed oczami czytającego. Był on siłą sprawczą zatrudnienia Żmichowskiej w Instytucie Aleksandryjsko-Maryjskim. Wohl i Kapliński posłowali w tej

grafii Narcyzy Żmichowskiej), [w:] Sztuka pisania..., s. 233-243; B. Zwolińska, O kwestiach kobiecych w korespondencji Narcyzy Żmichowskiej, Gdańsk 2007; G. Borkowska, Solidarne i samotne, „Res Publica Nowa” 1993, nr 10; eadem, Podmiot epistolarny w listach Narcyssy do Wandy (O korespondencji Narcyzy Żmichowskiej i Wandy Grabowskiej), [w:] Przygody romantycznego "Ja". Idee - strategie - rezonanse, red. M. Berkan-Jabłońska i B. Stelmaszczyk, Poznań 2012, s. 189-202; U. Phillips, Religia w listach do Izabeli Zbiegniewskiej (1857-1876), [w:] eadem, Narcyza Żmichowska. Feminizm i religia, thum. K. Bojarska, Warszawa 2008, s. 316-355.

13 G. Borkowska (Cudzoziemki. Studia o polskiej prozie kobiecej, Warszawa 1996, s. 79) pisze: „Tym, co opisuje najlepiej (choć ciągle bardzo nieprecyzyjnie) twórczość Żmichowskiej, jest kategoria d z i w n o ś c i. Utwory Narcyzy są d z i w n e”. Dodajmy: dziwnością zasługującą na ciągłą refleksję naukową.

14 Tak o listach Norwida pisze A. Witkowska (A. Witkowska, R. Przybylski, Romantyzm, Warszawa 1997, s. 599). Zob. również A. Pekaniec, op. cit., s. 171.

15 List do brata Erazma, t. I, s. 165.

16 Ibidem, s. 191. 
sprawie do pisarki w 1862 roku w dzień jej imienin pod pretekstem złożenia życzeń, co zachowała na zawsze we wdzięcznej pamięci jako ślad życzliwości, ale i potwierdzenia słuszności wyboru tego „powinowactwa”. Seweryn zaś, przyjaciel i ulubieniec Jurgensa, tak zaprezentowany został w liście do Wohla: „dla kolegów jest przedstawicielem rzeczywistej wartości w zdolnościach i prawości charakteru, dla mnie jest czymś więcej jeszcze, jest żywym przypomnieniem i pamiątką umarłego" (W, III, 217). Jeszcze dobitniej wybrzmiewa to w liście do niego samego: „z Was sobie na własność wzięłam kilka lat waszej przeszłości z Jurg[ensem] spędzonych i całą Waszą przyszłość, w której widzę najjaśniejszy komentarz jego starganych fatalizmem planów” (M, III, 313). Widać wyraźnie, że tworzą grupę przyjaciół wzajemnie ciekawych swego losu. Żmichowska pisze do Wohla często o Markiewiczu, czasem o Kaplińskim, a bywa, że o obu równocześnie; w listach do Kaplińskiego wspomina o Wohlu, z Markiewiczem gawędzi o Miodogórzu, mieszkaniu przy ulicy Miodowej w Warszawie, na górze, czyli na trzecim piętrze kamienicy należącej do zaprzyjaźnionej rodziny Grabowskich, gdzie spotykali się wszyscy i gdzie narastała wzajemna ideowa bliskość oraz rodzinna niemal zażyłość. Wzmacnia więc „powinowactwa z wyboru", jakby w przeczuciu, że jej młodym przyjaciołom jest to potrzebne, aby mogli budować przyszłość, zahamowaną i niepewną, we wspólnocie i pamięci o tych, którym nie była ona dana w żadnej postaci. Z tak uporczywie odpominanej przeszłości płynie dla nich zobowiązanie pracy dla innych i szczęścia dla siebie.

W istocie są to zawsze listy z Miodogórza, choć czasem pisane w Olszowej, Zielonej, Dębowej Górze czy Pszczonowie, miejscowościach znaczących popowstaniowe rodzinne schronienia pisarki. Zasadniczą strukturę listów stanowi ch ro n ol o g i a w s p o m n i eń, w których swoiste dowartościowanie warszawskiej przestrzeni i skupionych tam ludzi („boża czeladka pobożniejsza od »bożej czeladki« Kraszewskiego” - K, III, 285 nlb.) służy budowaniu ch ro n ologi i na d zi e i, ta zaś musi wyminąć traumatyczną teraźniejszość, przerzucić most między przeszłością a przyszłością. Przywołuje więc Żmichowska wszystkie „odwiewy lat ubiegłych” (W, III, 276), aby stłumić rozpacz, mówi do swych bliskich „nie według teraźniejszych przekonań, ale według wspomnień” (M, III, 326). Miodogórze w sensie przenośnym, ale i dosłownym ma stać się „arką przymierza między dawnymi a nowymi laty”, ostoją dla rozbitków, którzy w tej przestrzeni (nawet jeśli będzie to tylko przestrzeń mentalna), wśród życzliwych ludzi ukoją rany ciała i duszy. Często pojawia się w listach projekt-obietnica z Miodogórzem w tle: „gdy wrócicie...”. Spotkamy się - marzy wbrew wszystkiemu i wszystkim Żmichowska - i znowu będzie jak dawniej; „Rozgadamy się wtedy o poczciwych ludziach i wartych czytania książkach, dwóch największych w systemacie słonecznym rzadkościach" (W, III, 259).

\section{Strategie starej ciotki}

Kiedy pisze swój pierwszy list do Henryka Wohla, on, przebywający na zesłaniu w Ussali, ma lat 28 , ona - 45. Ciotka? Tak, z wyboru, to już wiemy i można na to - nie bez pewnych obiekcji - przystać. Dlaczego jednak stara? Ta ważna składowa część autoportretu zawarta w omawianym bloku listów, często w nich przywoływana, poddawana namysłowi, przez co wręcz ostentacyjnie jawna, na pewno nie jest przejawem kokieterii, nie jest też „jakimś 
naddatkiem, lecz staje się składnikiem kreowania i komunikowania sensów” ${ }^{17}$. Jest częścią szerszej strategii Żmichowskiej.

W liście do tego właśnie „siostrzeńca z wyboru”, do którego długo pisała bez nadziei na odpowiedź, bo najpierw nie miał zgody na korespondencję, a potem listy często ginęły, zwraca uwagę, że te epistolarne korowody zakrawają na celową intrygę, która bywała w powieściach przyczyną rozłączenia kochanków. I dodaje: „Między nami nic podobnego zdarzyć się nie może, bo najpierw my nie kochankowie wcale, tylko po prostu przyjaciel-siostrzeniec i wierna przyjaciółka, stara ciotka ...” (W, III, 258).

Obserwujemy w czystej postaci „technikę zapobiegania niepożądanym interpretacjom"18. Żmichowska była czuła na te kwestie, bo jej korespondencja z braćmi, szczególnie z Erazmem, w młodości pełna egzaltacji, wywoływała u niektórych niezdrowe emocje: „Śmiać mi się chciało nawet - wyznaje ukochanemu i wyidealizowanemu bratu - jak wujenka Józefowa opowiadała mi historię w guście Rene Chateaubrianda, by mnie przestrzec, że siostra w bracie pokochać się może"19. Omawiane tu listy do mężczyzn sprowadza więc na wygodną płaszczyznę stosunków z dystansu, celowo nawet zwiększanego, ale jednak przyjacielsko-rodzinnego, przy czym rodzinnego jakby na wyższym poziomie, bo bez intryg (dziedziczenie, testamenty itp.), za to z prawem do bezceremonialności i „wymagalności", wręcz obowiązkiem wypowiadania niepokojów związanych z niepożądanym zachowaniem, działaniem czy brakiem działań.

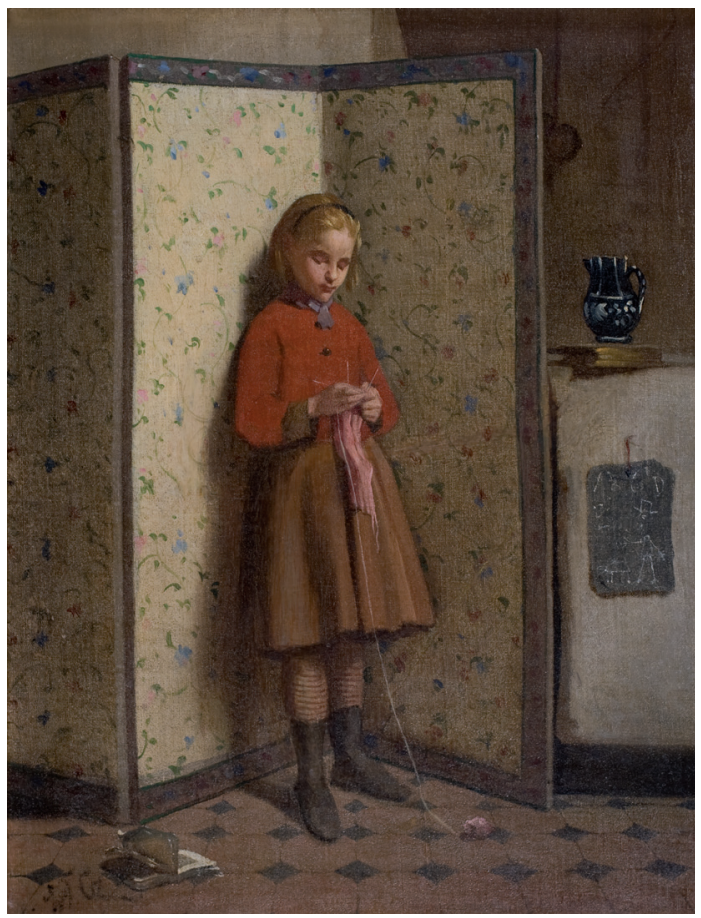

Władysław Czachórski, Dziewczynka

Fot. Anna Sierko-Szymańska. Ze zbiorów Muzeum Podlaskiego w Białymstoku

17 K. Cysewski, Problem autokreacji w listach Zygmunta Krasińskiego, [w:] Sztuka pisania..., s. 76.

18 Ibidem, s. 75.

19 List do Erazma, t. I, s. 71. 
A więc, owszem, wierna przyjaciółka, ale przede wszystkim ciotka. I jakby mało było tej wyrazistej dystynkcji (ciotka! nie: ciocia) - stara ciotka. Jak refren przewija się w omawianym bloku listów konstatacja: „jestem bardzo stara”, którą traktować trzeba nie tylko, a na pewno nie przede wszystkim jako rozpoznanie własnej sytuacji egzystencjalnej. To raczej ostentacyjne przyznanie sobie praw przynależnych „z wieku i urzędu”. Można potem wiarygodnie stwierdzić: „różne różności, różne chemiczne składy i rozkłady widziałam na własne oczy w tym laboratorium życia ludzkiego" (W, III, 242) i z pozycji osoby kompetentnej „opowiedzieć” przybranemu siostrzeńcowi jego samego, stawiając mu przed oczami te cechy (spokój dobroci, poczciwość, pracowitość), które chciałoby się w nim ocalić mimo niesprzyjających warunków; wypowiedzieć przy okazji podtrzymującą na duchu ufność wobec jego „prostej natury”, bo ta nie zmienia się tak łatwo jak najbardziej nawet szlachetne cechy nabyte. Wchodząc w rolę starej ciotki, można bezapelacyjnie uciąć: „... ale wiem lepiej od was wszystkich, że...” (W, III, 251), udzielić sobie przynależnych kochającej rodzinie praw do nagany i pouczeń: „Domyślacie się, że wedle zwyczajów, które względem moich ukochanych wiernie zachowuję, nawymyślałam mu za to porządnie...” (W, III, 250). Sprawa dotyczyła Seweryna, ale wnioski (,jestem pewna, że Wy [...] nigdy byście nie popełnili takiego grzechu”) - Henryka.

Wracając jednak do cytatu wykluczającego stosunki romansowe, warto zwrócić uwagę, że wybrzmiewa w nim pamięć o nieodległej sentymentalnej tradycji listów, która zostaje w ten sposób wyegzorcyzmowana. Inna, przejawiająca się nie tylko na płaszczyźnie uczuciowej, równość kobiety i mężczyzny uobecnia się w korespondencji Żmichowskiej. To niezmiernie dla niej ważna równość intelektualna. W związku z tym to, co dla nieskłonnych do porzucenia stereotypów mężczyzn mogło być niepokojąco emocjonalne lub wręcz egzaltowane, zyskuje w kolejnych listach inną, „zimną”, filozoficzno-społeczną, zobiektywizowaną motywację i z płaszczyzny osobistej przechodzi w wymiar społeczny, nawet jeśli obrazowane jest na własnym przykładzie, np. rozważania o problemie „samobadań wewnętrznych”, o „władzy wiedzenia o sobie, rozgmatwywania siebie” (M, III, 309) traktowanych nie jako „egotyczne kronikarstwo”, a głęboko ludzki obowiązek rozeznania się w swych możliwościach: „Muszę wiedzieć, czy jestem złą czy dobrą, ale muszę też wiedzieć, czy istotnie, co dobrym zwane, dobrze we mnie jest; co złym, źle we mnie jest” (M, III, 309). Starość zdaje się sądzić Żmichowska - daje prawo do przekazywania prostych prawd, które wszak okupione są trudną i długą jak życie nauką.

Stara ciotka to maska, zza której wychylają się, nie budząc niepokoju, kobiecość, rozum, inteligencja i ... mentorstwo. Ze znakiem poczciwości i domowej roztropności dają się w pełni zaakceptować. Kamuflaż ten pozwala na bezpieczną odległość zbliżyć się do młodych przyjaciól, którzy po 1863 roku, niepewni siebie i swego losu, znaleźli się w sytuacjach granicznych i nie tak łatwo pozwalali „słabym” kobietom pomóc sobie w sprawach pozamaterialnych; nie chcieli litości, pobłażliwości, a tym bardziej pouczeń i napomnień. Wszystko to wyklucza pisarka u zarania korespondencji, np. w pierwszym liście do Wohla: „nie posądzajcież mię tylko o zarozumiałą intencję pociechy” (W, III, 203 nlb.). Na wątpliwości Markiewicza reagowała równie zdecydowanie: „gdybym chciała Was pocieszać i dobrotliwie wspierać, miałabym wyborną sposobność $[\ldots]$ ale ja niedobrotliwa, przede wszystkim potrzebuję sobie każdego wytłomaczyć, a z niektórymi do współki rzecz zrozumieć” ( $M$, III, 313). Żmichowska, która wie o własnych „niedostatkach” (w listach tego nie ukrywa), nie mogąc niezbyt rozległymi wpływami czy stosunkami czegokolwiek ułatwić, nie pozwala 
im jednak zastygnąć w pozie męczenników czy rozbrojonych wojowników. Pokazuje, jak bardzo są potrzebni jej samej i wzywa do pracy nad sobą, która - to ważny cel - umożliwi pracę dla innych. „Bardzo Was i przyszłości Waszej potrzebuję dla drugich” - argumentuje w liście do Markiewicza. Wykreowana tak pieczołowicie starość ułatwia dowodzenie: „Generacja, do której ja należę, usuwa się z powierzchni ziemskiej. Nie mam o to do nikogo pretensji, tylko wytłumaczyć sobie nie umiem...” (W, III, 256). Przyszywani siostrzeńcy wzywani są w ten sposób do współmyślenia o tych, których znali (aby nie stali się dla nich obojętni), i o tym, co im było bliskie (aby nie oddaliło się nadmiernie). „Kiedy się nie wie, co o tym wszystkim najbliżsi nasi myślą, to jakby się wcale najbliższych sobie nie miało” (W, III, 259). Żmichowska sufluje im własne potrzeby tak, aby skłonić do refleksji i niejako wymóc korespondencję na nieskorych do pióra młodych przyjaciołach, którym - wie to lepiej od nich - epistolarny przymus może ułatwić „poskładanie” siebie i świata. Ma też nieskłamaną potrzebę, aby widzieć pewne sprawy oczami młodych. Tak jak nie skrywa, że jako starsza pewne rzeczy rozumie lepiej, bo na nie patrzyła, tak wie równocześnie, iż młodzi, właśnie ci wybrani, szlachetni i bezinteresowni, mogą jej objaśnić teraźniejszość i wszystkie wymogi najbliższej przyszłości, ponieważ „historyczna cząstka ich osobowości” kształtowała się w czasach jej samej już się wymykających:

Pytam, bo chcę Waszymi oczami wielu rzeczy dopatrzyć, bo wiem z pewnością, że Wasz wzrok żadnym osobistym interesem, ani żadnym moralnym przekupstwem nie zaćmiony, a szczególnie pytam dlatego, że Wy młodsi ode mnie i że jak w młodości bardzo szanowałam starość, tak teraz, gdym już sama ku starości znacznie przechylona, bardzo zaczynam młodość w jej prawach szanować (M, III, 333).

Usuwa się więc Żmichowska na drugi plan, ale nie czyni tego bezwarunkowo: „gdzie jest wybór, gdzie rozstajna droga, tak historyczne prawo decyzji przy młodszych, ale kiedy o jeden prosty gościniec idzie, umiem być bardzo niegrzeczną i upartą” (M, III, 315). Bardzo szybko ustala więc pisarka relacje wzajemności, zaufania i gotowości do współmyślenia, a to ułatwia znacznie takie d z i a ła n i a słowem, które gotowa jestem określić jako zabiegi mistrza wobec uczniów. Żmichowska - na odległość, w bezpiecznej masce - sprawuje wobec swych młodych przyjaciół rolę mistrza inicjacji. Wie i akceptuje fakt, że tym, co ich wszystkich łączy, jest smutek, ten sam, który jako brata bliźniaczego mądrości obserwowała w tym pokoleniu Orzeszkowa ${ }^{20}$. Żmichowska nie chce jednak, aby smutek i melancholia przeszły w rozmarzenie (kobiety) lub rozczulanie nad sobą (mężczyźni). Ma, jak sama określa, „talent domyślania się ludzi” (W, III, 249). Dlatego - była już o tym mowa - tak często „rozpowiada” im ich samych. Uzmysławia np. Henrykowi, kim jest jako człowiek, w swej istotności, w najgłębszych pokładach psychiki. Dokonawszy bilansu osobowości, rozpoczyna wobec niego wielki projekt przemiany wygnańca w uczonego, mobilizuje do heroizmu zarazem intelektualnego i etycznego. Planuje dla niego „studia nad podan[i] ami i językiem ludów", które żyją w jego sąsiedztwie. Wskazuje na potrzebę takich badań, wspierając się autorytetem profesorów uniwersyteckich, ale i własnym przykładem autorki Jeografii, dwutomowego podręcznika dla szkół. Organizuje i przesyła książki (niektóre trudne do zdobycia), wyjaśnia, jak z nich korzystać w związku z zachwianą kolejnością po-

20 E. Orzeszkowa, Pisma zebrane, t. XXXVI: Gloria victis, red J. Krzyżanowski, Warszawa 1951, s. 251-252. 
zyskiwania tomów, pokazuje znaczenie nowej dla „ucznia” dziedziny i relacjonuje własny zachwyt nad pięknem tego, co odsłania się uczonym filologom „tak jak otchłań niebios, uprzystępniona cierpliwym żeglarzom” (W, III, 220). I zachęca, zachęca, zachęca. Wręcz domaga się działań, ponieważ na sobie samej doświadczyła (nie kryła tego w listach), że książka może odciągać od myślenia.

Z Waszymi zdolnościami, z Waszym charakterem szczególniej niepodobna Wam się przecięż zupełnie od pracy umysłowej oderwać. Wiem, że się w książki zaopatrzacie, że lubicie czytać, lubicie używać umysłowo, to wszystko jednak jest dopiero konsumencją inteligencyjną, ja przychodzę o produkcją się dopomnić (W, III, 207).

Czekając cierpliwie na „produkcję”, chce otrzymywać natychmiastowe odpowiedzi na niektóre szczegółowe pytania; mobilizuje więc do nawiązania kontaktów z miejscowymi badaczami, choć nakazuje również „siostrzeńcowi” sformułowanie owych problemów badawczych we własnym imieniu, bo - zwróćmy uwagę na przyczyny ponownego kamufla$\dot{z} u$ - „Gdyby uczony z powołania, z urodzenia uczony dowiedział się, że go kobieta zapytuje, gotów by naumyślnie o tym się nie dowiadywać, a jak kolega poleci, będzie zaraz względniejszy" (W, III, 220). Po nieudanej akcji wykierowania Henryka na filologa, podejmie pisarka jeszcze jedną próbę, tym razem ukształtowania badacza natury.

Przejmujące w owej misji inicjacyjnej są listy do Seweryna Markiewicza, któremu - po licznych uzgodnieniach i wyjaśnieniach, że korespondencja jest obopólnie korzystna i nie ma w niej intencji pocieszycielskich - Żmichowska towarzyszy najpierw w pełnym nadziei dochodzeniu do zdrowia, a potem $\mathrm{w}$ powolnym umieraniu na gruźlicę. W zasadniczym swym zrębie i „na powierzchni” korespondencja ta jest ciągłym rozpatrywaniem „kwestii”, które podsuwa bieżące życie, odważnym intelektualnym mierzeniem się z problemami stawianymi przez Seweryna i obiekcjami zgłaszanymi z punktu widzenia kobiet, a także w ich imieniu przez Żmichowską (będzie jeszcze o tym mowa w dalszej części rozważań). Podskórnie pulsuje ona tajonymi emocjami i - czytana na tle całego omawianego bloku listów - daje się opowiedzieć jako historia „przedzgonnych” relacji przyjaciól, którzy na progu życia i śmierci doświadczają prawdziwie ludzkiej pocieszycielskiej bliskości. W liście do Wohla Żmichowska, która cały tydzień spędziła przy łóżku Seweryna, opowiadając mu swe „o przyszłym życiu rojenia”, tak przedstawia ostatnie chwile przyjaciela:

[... ] mówił dużo o wszystkim i wszystkich, szczególniej o tych, których kochał. Siła woli zesłabła i prawdziwa jego natura, z całą kobiecą tkliwością swoją, rozwinęła się bez żadnych naciśniętych na nią foremek. Spokojny był jak mistyk najpobożniejszy, a trzeźwy, logiczny jak badacz studium ciekawym zajęty (W, III, 264).

W tym misterium umierania oboje - i mistrzyni, i uczeń - doznają „wspólnoty rzeczy ostatecznych”21 i jakiejś pozareligijnej wzniosłości. Śmierć staje się egzystencjalnym problemem, który trzeba wyjąć z gotowych, więc również religijnych formul. Przedśmiertne obcowanie z tym „siostrzeńcem” to jakby pogański sympozjon. Długie, raczej pogodne, pełne wzajemnego zrozumienia rozmowy dążą - odnosimy takie wrażenie - do wykreowa-

\footnotetext{
21 Z. Mocarska-Tyc, Temat śmierci w prozie realistów, [w:] Problematyka religijna w literaturze pozytywizmu i Młodej Polski. Świadectwa poszukiwań, red. S. Fita, Lublin 1993, s. 138.
} 
nia zaświatowego Miodogórza. Żmichowska czuje wdzięczność, że Seweryn przyjął ją za „składową cyfrę w osobistych dziejach swoich”, i wyznaje: „Miałam wprawdzie [...] bardzo mi drogich przyjaciół $[. .$.$] ale przyjaciele byli na życie, na rozmowę poufną, zajmującą, na$ wspólny przedmiot ukochania, paru ledwie na wspólną pracę, a na śmierć on tylko je d e n" (W, III, 264).

W strategii „starej ciotki” to zdarzenie piękne, wzniosłe acz niezmiernie bolesne. Tak naprawdę chciała bowiem przygotować swych młodych przyjaciół do życia i szczęścia, a nie śmierci. Dlatego szczególnie istotna była dla niej listowa rozmowa z tym, który to, co projektowała, osiągnął, z Edwardem Kaplińskim: „Dziękuję Wam za pamięć, za poczciwe słowo i za ciche szczęście Wasze wśród zawieruchy ogólnej, bo to nie jest szczęście egoizmu ani obojętności - to naddatek jedynie ułatwiający przeczekanie złego i zrozumienie przyszłości” (K, III, 285 nlb.). To najbardziej zwięzła część omawianego bloku, on jeden nie potrzebował pociechy i wyprowadzania z melancholii.

\section{Zdarzenia, analizy, z n a c z e n i a}

A więc nazwaliście mnie „dobrą”, panie Sewerynie. Niech Was za to kiedyś coś bardzo szczęśliwego spotka. Widać, żeście mi prawdziwie z serca dali ten upominek, i co więcej znaczy, widać, że umiecie cenić jego wartość rzeczywistą, choć najczęściej „obiegowa cena” jest niższą daleko. Towarzyski język wbrew ewangelicznemu zakazowi przyswoił sobie to słowo w bardzo okrojonym znaczeniu, strącił je do kategorii przymiotników, których się nawet konwencjonalna skromność nie żenuje (M, III, 311).

Początek listu do Seweryna Markiewicza, datowany: 28 stycznia, 1867, Pszczonów, potraktować można jako charakterystyczną próbkę omawianej korespondencji. Żmichowska pomija lub znacznie upraszcza typowe dla listów dziewiętnastowiecznych „formulatury incipitowo-submisyjne”22, jakby szkoda jej było czasu i miejsca na „foremki”; od pierwszych słów wchodzi w dialog, precyzuje, definiuje, drąży znaczenia, zapobiegając nieporozumieniom, formułuje zasadnicze pytania, odnosi się do życzeń korespondenta („Według życzenia Waszego melduję Wam ..."). Formuly końcowe wciśnięte bywają w ostatni akapit lub pominięte, podobnie jak podpis, który, jeśli już się pojawia na arkusikach skrzętnie wypełnionych drobnym czytelnym pismem, to w skrócie: N. Żmich., N. Żm., ciotka Narcyss., Narcyssa (jeden raz tak wyraziście w liście do Markiewicza).

Listy Żmichowskiej do miodogórskich przyjaciół nie są kurtuazyjnym podtrzymywaniem kontaktu; mimo ich długości i skrupulatnego czasem wyliczania tego, co dzieje się ze znajomymi, krewnymi i powinowatymi, nie są też niezobowiązującą pogawędką ani tym bardziej towarzyską plotką. Wiemy już, że przypominanie warszawskiej codzienności ma aktywizować pamięć, utrwalać dawne związki, wiązać z przeszłością d la p r z y z z o ści. Sama używa wobec szczególnie obszernych epistoł określenia „foliały” lub „dysertacje”, to ostatnie uznać można za trafne rozpoznanie ze względu na stałe dążenie autorki do rozu-

\footnotetext{
22 Ich funkcjonowanie w listach do Kraszewskiego pokazuje T. Budrewicz, Intytulacje i submisje w listach pisanych do Józefa Ignacego Kraszewskiego, [w:] Sztuka pisania ..., s. 197.
} 
mowego zgłębiania pojawiających się problemów, roztrząsania różnych racji, precyzowania sensów i negocjowania wniosków.

Takich rozbiorów semantycznych, jak ten w niewielkim fragmencie zaprezentowany wyżej, związany ze słowem dobroć, jest w listach sporo. Tłumaczy więc np. Żmichowska Henrykowi, w jakim znaczeniu używa słowa „zazdroszczę” i dowodzi, że nadużycie językowe może „stać się omyłek historycznych lub, co gorzej, występków historycznych powodem" (W, III, 281). Zwykle zresztą nie o słowa chodzi, ale o dobrą wolę zrozumienia treści, które w intencji użytkownika za nimi się kryją: „Czy istotnie Wy się w szeregi konserwatystów zaliczacie? Mnie tam zresztą o nazwę nie chodzi, ale chciałabym wiedzieć z pewnością, co byście takiego utrzymać i zakonserwować chcieli” (M, III, 331). W swoich listach dysertacjach najczęściej sygnalizowała, kiedy i dlaczego używa nieprecyzyjnych sformułowań („bo się spieszę”), apelując wtedy, aby adresat sam je sobie „na poważniejszy przełożył dialekt", a potem - dla obopólnego dobra - ściśle dookreślił własne rozumienie istotnych pojęć. Argument był zawsze ten sam, wywiedziony z miodogórskich doświadczeń: trzeba skrupulatnie określić pole dyskusji, zdefiniować istotne pojęcia, nie dopuścić do językowych nadużyć. Kiedy więc dostrzegała potencjalną możliwość nieporozumień, drążyła problem i prosiła o dokładność, bo, jak wyjaśniła Markiewiczowi, „tym bardziej mi na tym zależy, bym mogła na Wasz punkt patrzenia trafić, w dalszym ciągu naszych listów czy rozmów już się wśród słów nie błąkać” (M, III, 331). Jednym z takich słów uparcie doprecyzowywanych jest miłość. Temat to ważny w projekcie egzystencjalnym Żmichowskiej, łączony zwykle z egzegezą pojęcia szerszego, w którym miłość ma się zmieścić, umożliwiając jego ziszczenie, mianowicie szczęścia. Jej przekonanie: „...p pewną jestem przecież, że ukochanie mogłoby być szczęściem zupełnym, gdybyśmy więcej i lepiej kochali” (M, III, 315), sformułowane zostanie w opozycji do wyrażonej w liście Markiewicza opinii, że „miłość i przywiązanie mogą być nieprzyjaciółmi szczęścia” (M, III, 315). To dla pisarki twierdzenie bliskie herezji. Młodego korespondenta ratuje w jej oczach tytko to, że sformułował je jako pytanie. Nie chce dopuścić do nieporozumień w dalszej korespondencji. Uparcie powraca do sprawy w kolejnych listach. Dlatego „miłość”, „szczęście”, „ukochanie”, „szczęście ukochania” to słowa zawsze w omawianych listach podkreślane, wyróżnione już w sposób graficzny, ale przede wszystkim poddawane (podobnie jak w całej twórczości literackiej) szczegółowej analizie, po to, aby odebrać im „formułkowość”, wyjąć z języka potocznego, przez uniezwyklenie skierować na nie uwagę, wymusić na odbiorcy drążenie ich istoty.

Ciekawie wybrzmiewają również zmagania Narcyssy z pozytywizmem, „pozytywnością, jak sama to określa, z teoriami Darwina i z darwinizmem. Przy wszystkich swych zastrzeżeniach ceniła naukowców pozytywistów za jasność sformułowań. Dlatego w liście do Wohla pewnego $\mathrm{z}$ nich broniła wbrew opiniom najbliższych, odkrywając $\mathrm{w}$ nim pokrewną duszę w dążeniu do pedantycznej niemal akuratności w formułowaniu myśli:

Ogromnie dużo już umie, ciągle za prawdą śledzi i ma taką naiwną potrzebę prawdy, że gdy rozmawia nawet wieczorną, wizytową gawędką, to żadnego k o b i e c e g o f r a z e s u [wyróż. E. O.] nie przepuści bezkarnie, zaraz na nonsens lub paradoks przetłumaczy, a gdy sam mówi, to $\mathrm{z}$ taką rozwagą, jak gdyby w głowie najętego krytyka do własnych słów trzymał, lecz nie wygląda to przesadnie, owszem, jako wspomniałam, robi wrażenie rzetelności (W, III, 254). 
Z takim rozmówcami lubiła się różnić. Jej idiosynkrazja wobec „kobiecego frazesu” i dystans wobec obowiązującego w XIX wieku stylu epistolograficznego są zastanawiające. Nie wiąże Żmichowska tych spraw z płcią. Kobiece frazesy oznaczają tu zapewne wszystkie, także przez mężczyzn stosowane, zgrabne i niekonfliktowe obejścia istoty rzeczy, wszystko, co jest mówieniem dla mówienia, towarzyskim (salonowym, listowym) „galopem konwersacyjnym”23. Ale właśnie kobietom chciałaby zapisać specjalną kurację, bo one „grzeszą” częściej i, pozbawione stosownej edukacji, nieświadomie. Byłaby to „kuracja autorstwa”. Wytłumaczyła to w liście do Seweryna, pisząc mu o tym, dlaczego namawia Wandę Grabowską i jego siostrę do tłumaczenia powieści angielskich:

Zupełnie inną jest rzeczą myślić dla kogoś, niekoniecznie w charakterze prawodawcy-objawiciela $[\ldots]$ ale myślić w odniesieniu do czyjejś innej myśli, z poczuciem odpowiedzialności za to, co podajemy, co nieuchylonym obowiązkiem sformułowania się logicznego od początku przez środek do końca. Wierzcie mi, że wyborna dla duszy higiena. Kto autorstwa kobietom zabrania, nigdy się nad ich psychologią sumiennie nie zastanowił (M, III, 319).

Ucząc kobiety „męskich strategii językowych”24, Żmichowska chciała je wyprowadzić z obszaru niesłyszalności. Pisarka sumiennie, skrupulatnie i bez egzaltacji zastanawia się nad kobietami. Rzecz znamienna, nie w listach do Kaplińskiego, uznanego wszak za wzorzec szczęśliwego ojca rodziny, mimo społecznych oraz swego czasu politycznych zobowiązań odnajdującego szczęście w codzienności, ale do tych, którzy wybór żony, „najpiękniejszy męskości przywilej” (W, III, 275), mają przed sobą. Powinni więc zastanowić się nad psychologią kobiet oraz ich pozycją i sytuacją życiową, tym bardziej iż wyczuwa w nich pisarka intelektualną gotowość, ale i pewien rodzaj empatii związany z „kobiecą” stroną ich męskich - co nie wymaga dowodów - charakterów. Idealizuje wręcz ich „kobiecą tkliwość”, „kobiecą prawdziwie dobroć”, cechy będące wynikiem szczególnego rodzaju doświadczeń życiowych, niejako przy okazji „rozbrajając” obowiązujący wzorzec męskości. W tym samym liście, z którego pochodzi cytat o kuracji autorstwem, stawia pisarka przed oczami odbiorcy problem kobiecego, przepastnego, według jej ujęcia, smutku. Owszem, pamięta, iż pisała niejednokrotnie o tym, że wszyscy jej najukochańsi byli i są smutni. Trudno bowiem leczyć ból egzystencji. Kobiety jednak nie znajdują lekarstwa na swoje tzw. złe humory, bo nie rozumieją ich mężczyźni, ratunku upatrujący zwykle w małżeństwie, jak Seweryn, którego dywagacje o „Malthusowym prawie” stały się powodem riposty Żmichowskiej:

Złe humory to zupełnie co innego jak prawdziwy gatunkowy, coraz częściej w najszlachetniejszych duszach rozwijający się smutek; bo też niezrzeczywistnienie wielu życzeń i marzeń to zupełnie co innego jak brak celu przed sobą, brak ześrodkowania obowiązku z pracą, ideału z praktyką (M, III, 324).

„Wam mężczyznom” - oskarża dalej Żmichowska - trudno to zrozumieć, bo wy nie „zużywacie się w bezobowiązkowej pracy”, w „marnej krzątaninie”. Kobietom potrzebny

\footnotetext{
${ }^{23}$ Jak pisze U. Philips (op. cit., s. 366), dekonstruuje Żmichowska każdy stereotyp, „jak również zasadę tworzenia stereotypów per se".

24 G. Borkowska, op. cit., s. 83.
} 
jest cel w życiu. Czasem, aby nadać sens ich krzątactwu ${ }^{25}$, wystarczy „pewność, że się p r z y $\mathrm{d}$ a” to, co robią. Innym, tym bystrzejszym, lepiej wykształconym, potrzeba jeszcze przekonania, że uczestniczą w tworzeniu dobra ogółu. „Dajcie im ten punkt i ten zenit, dajcie pracę obowiązkowo użyteczną a idealnie uświęconą, zobaczycie, jakie w nich siły wstąpią" (M, III, 324). Nie powinien budzić zdziwienia patos i ideowe posłannictwo. Żmichowska mówi o najważniejszych dla siebie, dla kobiet sprawach, a mówi do kogoś zdolnego to zrozumieć, do pojętnego i wrażliwego siostrzeńca z wyboru, którego los jest dla niej tak samo ważny jak los „uciśnionych” kobiet. Prezentuje nie uzurpacje tych, które dotąd skrywały swój smutek i rozgoryczenie, ale splot wspólnych interesów, palącą potrzebę głębszego wzajemnego zrozumienia. „Wy mężczyźni” nie jest tu sygnałem ironicznego dystansu, raczej prostą konstatacją dotyczącą inności poznania i doznania wynikających z różnicy położenia społecznego i uwarunkowań biologicznych. Dlatego autorka Poganki podejmuje, niejednokrotnie, rozpisany na wiele stron listów do Seweryna namysł nad tym, „kto kogo lepiej znać może, czy kobiety mężczyzn, czy na odwrót” (M, III, 306). Najpierw referuje rzeczywistą dyskusję nad tą kwestią, która zajmowała grupę przyjaciół z Miodogórza poszerzoną o uczonego filologa poznanego z poręczenia Markiewicza. Okazuje się, że maska starej ciotki ułatwia zażegnanie gorącego sporu: „Próbowałam wmówić w obradujących, że stary człowiek nie jest już ani kobietą, ani mężczyzną, więc jako stara i z nich wszystkich najstarsza, mam prawo zadecydować” (M, III, 307). Nie zdradza, jakie rozstrzygnięcie wybrała. Skłania „siostrzeńca” do własnych przemyśleń. Potem, w następnym liście, powraca do tej „szarady”, prezentując rozstrzygnięcie iście salomonowe, „że ani mężczyźni nie znają kobiet, ani kobiety mężczyzn”. Wytłumaczenie tego faktu jest już jednak, jak zawsze u Żmichowskiej, dogłębne i rzetelne, a wnioski w szczegółach interesujące także z tego powodu, że mają charakter persewerującego uprzytomnienia (zwłaszcza w części odnoszącej się do człowieka-kobiety), które zna każdy, kto czytał jej utwory literackie: „kobiety nie znają dobrze mężczyzn, ale za to lepiej znają człowieka w mężczyźnie. Przeciwnie, wy, moi panowie, znacie często doskonale kobietę jako kobietę, ale nie znacie człowieka w kobiecie" (M, III, 317). Czy przekłada się to na praktykę życiową? Oczywiście. I Żmichowska dokładnie to „siostrzeńcowi” uzmysławia.

Z Miodogórza, jak z kłębka najistotniejszych sensów, kiedyś tam właśnie powiązanych usilną pracą intelektualną, jak z motka ożywczej pamięci wywijają się listowe rozmowy o treści filozoficznej, moralnej, egzystencjalnej, a więc te, których waga problemowa odbija się w dostojnym, wręcz patetycznym stylu. „Czy pamiętacie?” - zapytuje wtedy Żmichowska któregoś z siostrzeńców z wyboru: „Gdybyście mogli sobie przypomnieć jedną naszą o Apostołach Renana rozmowę, łatwiej by Wam przyszło ciąg mej nitki rozeznać" (M, III, 310). Ciąg ów prowadzi od Arystotelesa, Konfucjusza, Chrystusa przez Cuviera do współczesności. I ułatwia sformułowanie wniosku, który nie bezpośrednio, nie na zasadzie doraźnego pocieszenia, lecz jako głęboka prawda wywiedziona z osobistych przeświadczeń (proces myślowy został zaprezentowany) ciotki nauczycielki nadaje sens cichym i tragicznym - jak życie Seweryna - egzystencjom zwykłych ludzi. Chrystus uposażył ludzkość „nowymi władzami ducha, zdolnością do cnót wyższych” (M, III, 310). To właśnie daje nadzieję. Żmichowska odwołuje się do sła w n y ch i m i o n, aby na ich przykładzie pokazać

\footnotetext{
25 O ten „sposób bycia w codzienności”, który tym słowem oddaje Jolanta Brach-Czaina (Szczeliny istnienia, Kraków 1999, rozdz. Krzątactwo), chodzi również Żmichowskiej.
} 
podobną drogę wielu b e z i m i e n n y c h, którzy „jak Chrystus przez ukochanie do ukochania”, przez własny przykład pomagają innym, „by takimi byli jak oni”: „Póty nie zginie cząstka dobrej osobistości, póki jej wpływ nie zginie; póty trwa, póki trwają ci, którzy ją ocenić umieli, którzy z niej korzystać mogli, którzy nią wspomożeni innych sobą wspomagają" (M, III, 311). Ustala pisarka ciąg „dziedziczenia”: od Jurgensa, którego zdaje się mieć na myśli, przez młodych skupionych wokół niego i - jak Seweryn - będących „pamiątką umarłego”, do tych dopiero przygotowujących się do przejęcia depozytu pamięci, aby przechować go „w wielkim skarbcu ludzkiej rasy ulepszenia”. Gotowa jest wybaczyć zapomnienie Renana i wielu innych rzeczy, apeluje jednak w ostatnich słowach listu: „Tylko nie zapomnijcie naszej rozmowy w szafirowym Wandy pokoju” (M, III, 311).

Miodogórze, miejsce symboliczne, nasycone znaczeniami i wartościami, odsyłające do przeszłości, ale nakierowane na przyszłość, dawało pisarce prawo, jak również moralny obowiązek do działań, które rozpoczęła niemal dzień po. W dzień po klęsce tylko do „najserdeczniejszego i najcenniejszego z adoptowanych siostrzeńców”, posiadającego „amulet z osobistego szczęścia”, odważyła się skierować słowa pełne tragizmu i gorzkiej ironii: „Bo i cóż? Świat się nie kończy i historia powszechna nie przerywa, choć jedna generacja umiera w boleściach, tyko boleść przesłania dalsze horyzontu grania” (K, III, 265 nlb.). Innym, tych mniej szczęśliwym, dzień po otwierała, mimo boleści - jak prawdziwa mistrzyni życia - nowe horyzonty.

\section{Bibliografia}

Baranowski Ignacy, Pamiętniki, Poznań: Gebethner i Wolff, 1923.

Borkowska Grażyna, Cudzoziemki. Studia o polskiej prozie kobiecej, Warszawa: Wydawnictwo Instytutu Badań Literackich PAN, 1996.

—, Podmiot epistolarny w listach Narcyssy do Wandy (O korespondencji Narcyzy Żmichowskiej i Wandy Grabowskiej), [w:] Przygody romantycznego "Ja". Idee - strategie - rezonanse, red. Maria Berkan-Jabłońska i Barbara Stelmaszczyk, Poznań: Wydawnictwo Naukowe UAM, 2012.

—, Solidarne i samotne, „Res Publica Nowa” 1993, nr 10.

Brach-Czaina Jolanta, Szczeliny istnienia, Kraków: Wydawnictwo eFKa, 1999.

Budrewicz Tadeusz, Intytulacje i submisje w listach pisanych do Józefa Ignacego Kraszewskiego, [w:] Sztuka pisania. O liście polskim w wieku XIX, red. Jolanta Sztachelska i Elżbieta Dąbrowicz, Białystok: Wydawnictwo Uniwersytetu w Białymstoku, 2000.

Cysewski Kazimierz, Problem autokreacji w listach Zygmunta Krasińskiego, [w:] Sztuka pisania. O liście polskim w wieku XIX, red. Jolanta Sztachelska i Elżbieta Dąbrowicz, Białystok: Wydawnictwo Uniwersytetu w Białymstoku, 2000.

Kirchner Hanna, Natkowska albo życie pisane, Warszawa: Wydawnictwo WAB, 2011.

Kuziak Michał, Kreacje epistolograficzne Juliusza Stowackiego (zarys problematyki), [w:] Sztuka pisania. O liście polskim w wieku XIX, red. Jolanta Sztachelska i Elżbieta Dąbrowicz, Białystok: Wydawnictwo Uniwersytetu w Białymstoku, 2000.

Mocarska-Tyc Zofia, Temat śmierci w prozie realistów, [w: ] Problematyka religijna w literaturze pozytywizmu i Młodej Polski. Świadectwa poszukiwań, red. Stanisław Fita, Lublin: Towarzystwo Naukowe Katolickiego Uniwersytetu Lubelskiego, 1993. 
Nawrocka Ewa, „[... ] list to nie stowo”. O listach Stowackiego do matki, [w:] Sztuka pisania. O liście polskim w wieku XIX, red. Jolanta Sztachelska i Elżbieta Dąbrowicz, Białystok: Wydawnictwo Uniwersytetu w Białymstoku, 2000.

Orzeszkowa Eliza, Pisma zebrane, t. XXXVI: Gloria victis, red. Julian Krzyżanowski, Warszawa: Książka i Wiedza, 1951.

Pekaniec Anna, Czy w tej autobiografii jest kobieta? Kobieca literatura dokumentu osobistego od poczatku XIX wieku do wybuchu II wojny światowej, Kraków: Księgarnia Akademicka, 2013.

Phillips Ursula, Religia $w$ listach do Izabeli Zbiegniewskiej (1857-1876), [w:] eadem, Narcyza Żmichowska. Feminizm i religia, tłum. Katarzyna Bojarska, Warszawa: Instytut Badań Literackich PAN, 2008.

Skwarczyńska Stefania, Teoria listu, Lwów: Towarzystwo Naukowe, 1937.

Stępień Marian, Narcyza Żmichowska, Warszawa: Państwowy Instytut Wydawniczy, 1968.

Watt Ian, Narodziny powieści. Studia o Deffoe'em, Richardsonie i Fieldingu, thum. Agnieszka Kreczmar, Warszawa: Państwowy Instytut Wydawniczy, 1973.

Witkowska Alina, Ryszard Przybylski, Romantyzm, Warszawa: Wydawnictwo Naukowe PWN, 1997. Woźniakiewicz-Dziadosz Maria, Dzieje przyjaźni entuzjastek w świetle listów Narcyzy Żmichowskiej do Bibianny Moraczewskiej, Lublin: Wydawnictwo UMCS, 2002.

—, List pisarza w przestrzeni autobiograficznej (Przypadek epistolografii Narcyzy Żmichowskiej), [w:] Sztuka pisania. O liście polskim w wieku XIX, red. Jolanta Sztachelska i Elżbieta Dąbrowicz, Białystok: Wydawnictwo Uniwersytetu w Białymstoku, 2000.

Zwolińska Barbara, O kwestiach kobiecych $w$ korespondencji Narcyzy Żmichowskiej, Gdańsk: Wydawnictwo Uniwersytetu Gdańskiego, 2007.

Żmichowska Narcyza, Listy, t. I: $W$ kręgu najbliższych, Wrocław: Ossolineum, 1957; t. II: Rozdroża, Wrocław: Ossolineum, 1960; t. III: Miodogórze, Wrocław: Ossolineum, 1967; t. IV: Rozmowy z Julia, z rękopisu wydała B. Winklowa, Warszawa: Instytut Badań Literackich PAN, 2009; t. V: Narcyssa i Wanda, wydały B. Winklowa i H. Żytkowicz, Warszawa: Instytut Badań Literackich PAN, 2007. 